\title{
Natural Theology in Evolution : A Review of Critiques and Changes
}

\section{Kojonen, Rope}

2017

Kojonen , R 2017 , ' Natural Theology in Evolution : A Review of Critiques and Changes ',

European Journal for Philosophy of Religion, vol. 9 , no. 2 , pp. 83-117 . https://doi.org/10.24204/EJPR.V9I2.1935

http://hdl.handle.net/10138/310089

https://doi.org/10.24204/EJPR.V9I2.1935

acceptedVersion

Downloaded from Helda, University of Helsinki institutional repository.

This is an electronic reprint of the original article.

This reprint may differ from the original in pagination and typographic detail.

Please cite the original version. 


\title{
Natural Theology in Evolution: A Review of
}

\section{Critiques and Changes}

\author{
Dr. Erkki Vesa Rope Kojonen \\ University of Helsinki, Faculty of Theology
}

\section{Abstract}

The purpose of this article is to provide a broad overview and analysis of the evolution of natural theology in response to influential criticiques raised against it. I identify eight main lines of critique against natural theology, and analyze how defenders of different types of natural theology differ in their responses to these critiques, leading into several very different forms of natural theology. Based on the amount and quality of discussion that exists, I argue that simply referring to the critiques of Hume, Kant, Darwin and Barth should no longer be regarded as sufficient to settle the debate over natural theology.

\section{Introduction}

Adam, Lord Gifford (1820-1887), who in his will sponsored the ongoing Gifford Lectures on natural theology, defined natural theology quite broadly as "The Knowledge of God, the Infinite, the All, the First and Only Cause, the One and the Sole Substance, the Sole Being, the Sole Reality, and the Sole Existence, the Knowledge of His Nature and Attributes, the Knowledge of the Relations which men and the whole universe bear to Him, the Knowledge of the Nature and Foundation of Ethics or Morals, and of all Obligations and Duties thence arising." Furthermore, Gifford wanted his lecturers to treat this natural knowledge of God and all of these matters "as a strictly natural science, the greatest of all possible sciences, indeed, in one sense, the only science, that of Infinite Being, without reference to or reliance upon any supposed special exceptional or so- 
called miraculous revelation. I wish it considered just as astronomy or chemistry is." (Gifford 1885) John Hedley Brooke, one of the premier historians of the relationship of science and religion, similarly defines natural theology as "a type of theological discourse in which the existence and attributes of the deity are discussed in terms of what can be known through natural reason, in contradistinction (though not necessarily in opposition) to knowledge derived from special revelation." (Brooke 2002, 163-164)

Natural theology as thus understood has been subjected to much critique from several different directions. Can knowledge of God truly be a science comparable to astronomy and chemistry? And can (or should) knowledge of God truly be obtained without special revelation from God, purely on the basis of human reason and experience? Isn't religious faith just about faith without any basis in reason - what does faith have to do with evidence? Natural theologians have faced critique from both the natural sciences, philosophy and theology. The power of the critiques is commonly perceived to be very strong, and the existence of some contemporary defenders of natural theology is sometimes met with incredulity. Have such natural theologians not heard of Kant, Hume, Darwin and Barth?

However, contemporary natural theologians are well aware of the ideas of Hume, Kant and Barth, and have attempted to formulate natural theology to avoid these critiques (e.g. Craig \& Moreland ed 2012; Sennett \& Groothuis ed 2005). While some overviews of aspects of the discussion are available (e.g. Taliaferro 2012 \& 2013; Moore 2013; Sudduth 2009; Holder 2012; Pannenberg 1991, 73-118), the overall broad nature of the evolution of natural theology still deserves to be discussed further. The purpose of this article is to provide an overview of the overall evolution of natural theology, and how multiple alternative forms of natural theology can be mapped out in response to the traditional critiques. In briefly analyzing the various ways in which natural theologies have been formulated, the article also seeks to advance the discussion over how what really is essential for a theology to be considered a natural theology. I conclude that natural theology has evolved sufficiently that theologians should no longer consider simply referring to the traditional critiques to be a sufficient rebuttal of natural theology. I will begin with some overall considerations about the definition of natural theology, then go on to discuss the traditional critiques and different lines of response to them. 
As the article will show in more detail later, contemporary natural theologians take vastly different approaches in answering the critiques of Hume, Kant and Barth. ${ }^{1}$ For example, a person selfidentifying as a natural theologian might think that we have only weak evidence of God, and that natural theology is a unnecessity for the rationality of religious faith. However, another person adopting the term "natural theology" might think that we have strong evidence of the existence of God, that natural theology is necessary for the rationality of religious faith. The nature of the evidence and argument forms that are used can also create very different natural theologies.

Given the variety of natural theology, one might ask if these views are actually too different to all fit under the label of "natural theology". Accepting such a variety of views as species of natural theology threatens to divest the term of all meaning. One possible reply to this objection would be to argue that all the differents forms of natural theology do fit under the some highly unspecific definitions of natural theology, such as Macquarrie's $(1975,137)$ definition: "the function of natural theology was to provide a connection between our ordinary everyday discourse about the world and even our scientific discourse on the one side, and theological discourse on the other." This is indeed a function of all forms of natural theology, but it may be too broad. ${ }^{2}$ Most contemporary theologies attempt to connect theology to our current situation and other discourses, but calling all of these theologies "natural" would also threaten to remove the value of the term. ${ }^{3}$

\footnotetext{
${ }^{1}$ If we consider Intelligent Design to be a part theology, then the variety of responses increases further. Then we could also classify natural theologies based on their response to Darwin as part of the response to the "critique of the evidences of natural theology". However, proponents of ID do not themselves consider their arguments to be natural theology, but natural science. This is why they criticize methodological naturalism as a ground rule of science (Kojonen 2016d). Critics of ID also often do not consider ID to be proper natural theology, but rather a "God of the gaps" -argument. However, drawing these borders can be difficult. On this see Kojonen 2016b.

${ }^{2}$ According to Wolterstorff (1986), Thomas Aquinas identified three main purposes of natural theology: 1) to seek for truth about God which can be known based on natural philosophy, 2) to clear away objections to the faith through apologetics, and 3) to help transform faith into seeing through providing supporting arguments for beliefs initially accepted only based on faith.

${ }^{3}$ Pannenberg $(1991,101)$ criticizes such a broad definition of natural theology as follows: "If any relating of what is specifically Christian to general concepts, and especially to anthropology, is in the future to be called natural theology, then the term is one that can be adapted in any way one pleases to fit strategies of theological differentiation. For what theology can avoid describing what is specifically Christian in general concepts? Hence, while one might regard one's own theology as strictly a theology of revelation, one can easily detect traces of natural theology in that of all others."
} 
One way of specifying this definition further is to argue that the connections provided by natural theology must provide evidential support for religious belief. As William Alston $(1991,289)$ puts it, natural theology is "the enterprise of providing support for religious beliefs by starting from premises that neither are nor presuppose any religious beliefs". But some natural theologians (principally Alister McGrath) argue that natural theology should actually be practiced beginning from within the Christian tradition, with the aim of clarifying how this tradition makes sense of the world. As I understand his approach, McGrath does believe that natural theology does ultimately also result in providing some evidential support for the Christian faith. However, for him this is just a byproduct of natural theology, rather than being its primary defining characteristic or starting point (McGrath 2016, 176). I will comment on these issues further while discussing responses to critiques of natural theology.

For now I am focusing on the definition of natural theology, and the possibility for classifying natural theology in a way that allows us to include a wide variety of forms under this term. Rather than defining natural theology through just a single characteristic, an alternative approach would be to take a cue from the debate over the definition of religion and adopt a more multifaceted definition based on outlining different characteristics that are typical of natural theologies. ${ }^{4}$

In his own article in this issue, Olli-Pekka Vainio provides such a list of characteristics that usually go into a natural theology. Based on Vainio's list, I suggest that we can distinguish the following characteristics that are often present in natural theologies. The presence of merely a few characteristics in some form would not be enough to make a view a natural theology, but the absence of (or a strange formulation of) some characteristic also would not invalidate a theology from being a natural theology. I will list the characteristics here only briefly, though much more could be said about each. (1) Realism about theological claims: talk about God is understood as at least attempting to refer to a mind-independent reality. (2) Participatory ontology: some aspects of

\footnotetext{
${ }^{4}$ For example, Alston (1967) argues that we should not think of "religion" in terms of a single unifying characteristic, but rather a web of characteristics, many of which may be absent from a particular religion. Also, the existence of just a few of these characteristics may be insufficient to make something a religion. Alston's characteristic are (1) belief in supernatural beings, (2) a distinction between sacred and profane objects, (3) ritual acts focused on sacred objects, (4) a moral code believed to be sanctioned by the gods, (5) characteristic religious feelings such as awe, (6) prayer, (7) a worldview, (8) a total organization of one's life based on the worldview, and (9) a social group that more or less follows these tenets. While "religion" refers to the conjunction of a sufficient number of such characteristics, "theology" typically refers to the doctrine and way of thought associated with this religion. Summary from Kelly James Clark (2014, chapter 2).
} 
the natural world reflect something about its creator. It can vary greatly what aspects of nature reflect its creator, in what way, and how strong the compelling the reflection is thought to be. (3) A positive view of human reason: it is possible for human reason to recognize these aspects of the world as a providing evidence of God. There is variance in to what extent this is possible for human reason without being first healed of the negative noetic effects of sin through further supernatural aid. (4) A commitment to formulating the knowledge mediated through this natural revelation as arguments or proofs of the existence (or non-existence) and attributes of God. (5) Evidentialism: evidence is thought to be important for supporting the rationality of beliefs. (6) Spiritual worth: natural knowledge of God or evidence about God is thought to have some positive value for religious life.

Again, the idea is that having a different opinion on one or more of these characteristics might not be enough to disqualify some idea from being "natural theology", just as lacking one of the usual characteristics of a "religion" might not disqualify something from being a religion. We might argue that some characteristics are particularly important for a view to qualify as a proper natural theology: for example, the commitment to formulating arguments for the existence of God might be such a characteristic. Yet as I will show later, some do attempt self-identify as natural theologians without developing such arguments, and not without justification. Among the mainstream of natural theologians, there are also different understandings of how the arguments should be developed.

McGrath (2016, 22-25) similarly argues that the different approaches to natural theology can be best understood as different and complementary aspects of natural theology, akin to thin slices of a thick sandwich. This is not to say that natural theologians will in practice necessarily agree that some other form of natural theology is plausible, spiritually valuable or even coherent. As I will argue, contemporary natural theologians have vastly different strategies for responding to the traditional critiques of natural theology.

In a way, it might be argued that the variability of the forms of natural theology in history also shows that the critiques of Hume, Kant, Darwin and Barth cannot be straightforwardly applied against all forms of natural theology. As Brooke and Cantor (2000) and Pannenberg (1991, 73-107) argue, natural theology has taken many forms through history. There is no one authoritative definition of natural theology, and even the Gifford lectures exemplify many different views of the 
matter. Thus it might be argued that the particular forms of natural theology that Hume and Kant criticized do not exist anymore, and it is anachronistic to apply these critiques to contemporary natural theology. Rather, contemporary natural theologies must be examined on their own merits, and we must develop new critiques against them. I think this conclusion is ultimately right, but it is too fast. While differences between forms of natural theology are in the end quite large, there are also substantial overall similarities which make it possible to at least attempt to apply the same critiques against contemporary natural theologies. For example, in the debate over contemporary design arguments, Humean critiques of the explanatory power of theism in the face of the problem of bad design continue to be developed, and his critique of the logic of design arguments is also often referenced (see Kojonen 2016a, chapter 8). The traditional critiques of natural theology have also been so influential that it would be useful for the credibility of natural theology to show how they can be avoided. I move now to present an overview of these critiques.

\section{Traditional Critiques of Natural Theology}

The most influential philosophical critiques of natural theology have been presented by the Scottish philosopher David Hume (1711-1776) and the German philosopher Immanuel Kant (17241804). In his Dialogues Concerning Natural Religion Hume analyses the arguments of natural theology and presents both critiques and defenses of it through different characters, particularly focusing on the design argument. This makes the work difficult to summarize. Nevertheless, the critiques of natural theology presented by the character Philo have usually been taken to represent Hume's own views. Philo presents several different arguments against the viability of natural theology: (1) our inductive experience of the world cannot provide grounds for beliefs about unique events like the origin of the cosmos. (2) The design argument understood as an analogical argument fails, since the analogy between the cosmos and machines is very distant. (3) The problem of natural evil is counterevidence to the claims of the natural theologians: "Look round this universe. - - - The whole presents nothing but the idea of a blind nature, impregnated by a great vivifying principle, and pouring forth from her lap, without discernment or parental care, her maimed and abortive children." (Dialogues, part XI. Hume 2008b). (4) The arguments of the natural theologians cannot establish the identity of the creator, or whether there are one or many gods. (5) Natural theology leaves the mystery of the origin of God unexplained; if this is rational then it should be equally rational to leave the mystery of the origin of the cosmos unexplained. (6) 
The concept of God as a necessary being may even be incoherent, since we can conceive of God's nonexistence. ${ }^{5}$ (See further Penelhum 2005, Russell 2014)

For Kant, reading Hume's critiques both in the Dialogues and in his other work was like waking up from a "dogmatic dream", and his is reflected in his Critique of Pure Reason. Kant did have good things to say about teleological arguments as they were understood at the time: "Reason, constantly upheld by this ever-increasing evidence which, though empirical, is yet so powerful, cannot be so depressed through doubts suggested by subtle and abstruse speculation, that it is not at once aroused from the indecision of all melancholy reflection, as from a dream, by one glance at the wonders of nature and the majesty of the universe - ascending from height to height up to the all-highest." ${ }^{6}$ However, just as Hume argued that the conclusions of natural theology are insufficient for rational religious belief in God; Kant similarly claimed that the design argument can at most prove the existence of some sort of "architect" of the universe, rather than the existence of an "all-sufficient primordial being". ${ }^{7}$ According to Kant, using speculative reason to discern God's properties or to establish his existence is an error, because God is not spatio-temporal and cannot be the object of experience. He argues that we can only have reliable knowledge of things that can at least in principle be experienced. Although allowing that arguments can also presented in favour of beliefs about things that are beyond experience, Kant argues that in such cases an equally plausible argument can always be given for the contrary view. These he calls the "antinomies of pure reason." In his later works Kant grounds belief in God as necessity for the operation of "practical reason" rather than the arguments of natural theology (Rossi 2014). Natural theological arguments are, according to Kant, based on the humanly constructed concepts of pure reason, rather than being experientially grounded. Thus Kant calls natural theology "ontotheology". The critique of natural theology as "ontotheology" was since taken up by philosophers following Heidegger and also by many theological critics of natural theology (White 2016, chapter 1$){ }^{8}$

\footnotetext{
${ }^{5}$ Kai Nielsen takes the argument that the concept of God is incoherent further. According to Nielsen, even the stars spontaneously arranged themselves to form the sentence "GOD EXISTS", this would not be evidence of the existence of God, since such a sentence would be incoherent. (Nielsen 2004, 279. For discussion see Taliaferro 2013.)

${ }^{6}$ Kant 1957, 520 (A624/B652).

${ }^{7}$ Kant 1957, 522 (A627/B655).

${ }^{8}$ In this paragraph I have followed the traditional way of reading Kant's critique of natural theology. However, see Chignell 2009. See also Appelqvist's article in this issue.
} 
Karl Barth, possibly the most influential theologian of the $20^{\text {th }}$ century, was highly critical of natural theology. Barth's programme was to establish theology on its own foundation of the revelation of God, against theologies where human experience had become the foundation of theology. His critique of natural theology is related partly to his historical situation: Barth was worried that natural theology would leave theology open to becoming the servant of political ideologies such as Nazism. However, Barth's critique of natural theology is based on fundamental disagreements with natural theology that go far beyond Barth's own historical situation. He also objected to Emil Brunner's very moderate attempts at rehabilitating natural theology (Barth 1946[1934]). As a Gifford lecturer Barth argues that natural theology is diametrically opposed to Christian theology. He claims that from the point of view of natural theology true theology, the "teaching of the Reformation", is actually "the greatest of errors" (Barth 2005[1938], 7).

Indeed, natural theology is prohibited by Barth's understanding of God, humanity and revelation. Building on Lutheran and Kantian critiques of natural theology, Barth argued that natural theology ignores the infinite qualitative distinction between humanity and God (McCormack 1995). ${ }^{9} \mathrm{He}$ criticized the scholastic understanding of the analogia entis, which he understood to mean that the creation is somehow analogous or similar to God, and so can reveal God on the basis of this similarity..$^{10}$ Barth argued instead for the analogia fidei, according to which God can only be known through faith in God's own self-revelation in Christ. In building its system of theology upon reason, rather than divine self-revelation, natural theology is the antithesis of true Christian theology and true religious faith. Rather than attempting to persuade the world by constructing systems of thought based on fallen human reason, the Church should testify about God's revelation in Christ (see further White ed. 2010, Moore 2013).

\footnotetext{
${ }^{9}$ Note that Barth's understanding is more radical than that of early Lutherans, including Luther and Melanchton. See the article by Ilmari Karimies in this issue, as well as Sudduth 2009, 9-13 and Woolford 2011, chapter 3. However, regardless of what the views of the early Lutherans were, after Kant Lutheran theology came to be interpreted to be opposed to natural theology. See e.g. von Loewenich 1976.

${ }^{10}$ The way this "somehow" is construed is of course critical for the debate: if God and created beings are understood to share a common property of "being", critics argue that this makes God into just a "being among beings", rather than the transcendent Creator. Defenders of the analogie entis have contended that this misunderstands the term, and that the capacity of created things to reflect their creator must be understood in another way. (White 2016; White 2010 ed.)
} 


\section{Further Critiques of Natural Theology}

In the contemporary discussion, arguments by Hume and Kant continue to be repeated and developed against natural theology. Further critiques of natural theology have also developed, and here I will briefly describe what I call the scientistic critique of natural theology and theological antirealism. I indeed mean the "scientistic" rather than the "scientific" critique here. Scientific critique might be made against certain premises of certain arguments of natural theology, such as the biological design argument. (See Kojonen 2016a). However, scientism goes beyond this to assert that the natural sciences are our best or only way to know or form rational beliefs about reality. (Stenmark 2001; De Ridder, Peels \& van Woudenberg ed. forthcoming)

Insofar as the natural sciences are methodologically naturalistic, scientism would seem to rule out natural theology already on methodological grounds. This thinking has its roots in the logical positivism of the early $20^{\text {th }}$ century, in turn a development of Humean and Kantian ideas, though their ideas of what "science" was would have been far different. ${ }^{11}$ In the contemporary discussion, Alexander Rosenberg, who advocates scientism, argues that scientism "is the conviction that the methods of science are the only reliable ways to secure knowledge of anything - being scientistic just means treating science as our exclusive guide to reality, to nature - both our own nature and everything else's". (Rosenberg 2011,6-8) But scientism is rarely stated this explicitly. In the context of discussion about natural theology, it seems to me that we can also sometimes identify the influence of scientism in the standards of evidence and reasoning that are adopted, rather than scientism being an explicitly stated premise. ${ }^{12}$

Regarding theological realism, natural theology assumes that talk about God is meant to refer to a mind-independent reality that we can comprehend at least to some degree. Rather than being a fiction of the human mind, God is understood as the real creator of the universe. Theological nonrealism can be understood in various ways. For example, in full blown theological nonrealism it

\footnotetext{
11 Thus scientism also might be traced back to Hume. Hume's separation of empirical and a priori knowledge and his suspicion of metaphysics fits quite well with scientism: "If we take in our hand any volume; of divinity or school metaphysics, for instance; let us ask, Does it contain any abstract reasoning concerning quantity or number? No. Does it contain any experimental reasoning concerning matter of fact and existence? No. Commit it then to the flames: for it can contain nothing but sophistry and illusion." (An Enquiry Concerning Human Understanding, Section XII.) The same sentiment is echoed by contemporary scientistic thinkers who want the natural sciences to take over the discussion over the traditional questions of the humanities, philosophy and theology, or argue that the questions discussed in these disciplines are meaningless or unanswerable if they cannot be studied by the methods of natural science.

${ }^{12}$ For examples of this tendency in the discussion of design arguments, see Kojonen 2016a and Kojonen $2016 \mathrm{~b}$.
} 
is argued that religious language is not meant to refer to metaphysical entities, but to fulfill other functions. Theology is not about making truth claims. If this were to be the true understanding of theological language, then natural theology as an attempt to discuss the evidence for theological truth claims would be truly alien to religious faith. (Keller 2014, Rauser 2009)

Theological nonrealism is sometimes presented as a neutral Wittgensteinian analysis of the grammar of religious language (Phillips 1988). However, critics have long argued that it cannot truly be merely descriptive of religious language, but rather a normative account, since the vast majority of religious believers do believe in the mind-independent existence of God. Discussion of these issues is ongoing (Phillips ed. 2008), but the nonrealist position is definitely in the minority. This means that the presupposition of realism is not the most controversial presupposition of natural theology. Yet even if the nonrealist critique of natural theology fails in its strongest form, one might still argue that the primary purpose of religious language is not in making truth claims, and that the primary reasons for choosing a religious way of life are also not about metaphysics, even if religions do also make metaphysical truth claims. In that case one could argue that natural theology is at most a side-issue from the point of view of religious belief.

It seems to me that all of the foregoing critiques can be classified, following Charles Taliaferro's $(2013,385)$ terminology, into external and internal critiques. The external critiques deny the very possibility of natural theology already in principle whereas the internal critiques deny the viability of natural theology in practice. I classify the external critiques as follows:

1) The philosophical critique of the concept of God as incoherent: if such a concept cannot even be coherently formulated, then the project of natural theology fails to get off the ground. ${ }^{13}$

2) The epistemological critique of the possibility of natural theology: if the question of the existence or non-existence God is already in principle unanswerable or unthinkable by humans, then natural theology cannot get off the ground. I am thinking particularly of the Kantian epistemological critiques of natural theology.

\footnotetext{
13 Taliaferro (2013, 387-389) classifies this as an "internal" critique, but I think it is better classified as an external critique as it would prohibit any natural theology already a priori, rather than based on the assessment the compatibility of the evidence with various theological positions.
} 
3) A full-blown nonrealist understanding of theological language as a critique of natural theology: if religious language is not meant to refer to any mind-independent reality, then the presentation of natural theological evidence for the existence of such a reality misses the point.

The internal critiques listed above are the following:

4) The critique of evidentialism as the basis for requiring any natural theology. If belief does not have to be supported by the kind of evidence presented in natural theology, then this can be argued to make natural theology unnecessary. I classify this critique as an internal critique, since it in itself does not establish that natural theology could not be possible or useful.

5) The critique of the arguments of natural theology. This can be done based on the explanatory poverty of theism or the lack of overall convincing evidence of the existence of God.

6) The critique of the relationship between natural theology and confessional theology. For example, the critique arise from theological understandings of God, human nature and salvation. Perhaps the concept of God used in natural theology is too far removed from the theological understanding of God to be of any use, and perhaps fallen human reason cannot benefit from any natural revelation of God. Furthermore, natural theology is sometimes argued to make belief in God into a human accomplishment, whereas faith should actually be understood as a gift from God or an act of God in humans. ${ }^{14}$

I will now turn to consider different types of responses to these critiques, with the goal of understanding the overall broad lines of the responses that are available and how this helps classify different types of natural theology.

It seems to me that contemporary defenders of natural theology are united in their answers to the listed three external critiques of natural theology (1-3). They agree that the concept of God is not incoherent, that reasoning about metaphysics is possible at least to some extent. They also want to say something about a real God, and are thus not antirealists about theological language. Natural theologians can take comfort that these affirmations are broad enough to be shared by many who

\footnotetext{
${ }^{14}$ I classify this critique as "internal" since such critics of natural theology might still maintain that the natural world reveals its Creator and that this might be discovered by humans if we were not fallen creatures.
} 
are not natural theologians. The mainstream of Western theology holds that the concept of God is not incoherent, the possibility of metaphysics has many defenders in contemporary philosophy (Tahko 2016), and the broad mainstream of religious believers and theologians believe that religious language tries to say something about a real God. (Keller 2014) However, the answers of contemporary natural theologians to the three internal critiques (4-6) differ considerably.

\section{The Critique of Evidentialism}

Regarding the critique of foundationalism and evidentialism (4), the mainstream position during the Enlightenment was indeed that evidence is absolutely necessary for religious belief. Thinkers like John Locke (1640-1703) held that reasonable belief in the truth of some proposition should always be proportioned to the evidence for that proposition. This way of thought was summed up by W. K. Clifford in his famous essay "The Ethics of Belief" as "it is wrong always, everywhere and for anyone to believe without sufficient evidence". (Clifford 1877[1999]) This emphasis on the necessity of publicly available evidence supporting belief would make natural theology an absolute necessity for the rationality of religious belief. This assumption about the ethics of belief has come under strong critique in recent decades, and natural theologians can take different positions. (McCarthy 1986; Chignell 2016)

For example, the natural theologian may follow Alvin Plantinga in arguing that many rational beliefs are not held on the basis of evidence and arguments. Rather, beliefs like "I see a tree" or "God loves me" can be properly basic beliefs, not requiring justification based on publicly available evidence or arguments. This would make natural theology unnecessary for the rationality of religious belief. However, it might still be valuable for reasons other than ensuring the rationality of religious belief. Plantinga himself argues that properly basic beliefs might receive further support based on evidence and arguments, and so his critique of classical foundationalism seems compatible with natural theology. ${ }^{15}$

\footnotetext{
${ }^{15}$ Plantinga's relationship to natural theology is complex. At points Plantinga critiques natural theology, arguing variously that it fails in establishing its conclusions sufficiently clearly and that its defenders err in assuming that natural theology is necessary for religious faith. (Plantinga 1982; 2000, 272-80. For responses, see Sudduth 2009 and Swinburne 2004b.) However, in other writings Plantinga allows that the warrant of religious belief can be increased if it is also supported by arguments, and that the arguments of the natural theologians are good and credible arguments, comparable to the best philosophical arguments. Plantinga also allows a role for natural theology in rebutting objections to religious belief. (e.g. Plantinga 1991). For a similar perspective, see Alston 1992 . On
} 
Alternatively, the natural theologian can admit the force of Plantinga's critique while continuing to hold that natural theology is quite important for the rationality of religious belief. For example, Swinburne agrees that people can have rational belief in God without arguments, based on things like religious experience and the testimony of authorities. However, he would classify these things as evidence. According to Swinburne (2004b), while a medieval peasant would be well justified in believing in God on such grounds, nowadays with the increased religious pluralism and the many objections to religious faith, natural theology is indeed necessary for the continued credibility of religious faith. For Swinburne, it is not necessary that each individual religious believer can present a natural theology, but at least somebody needs to be doing natural theology in order to maintain belief in the Christian God as a live option.

The natural theologian's response to the challenges to foundationalism and evidentialism will depend on the natural theologian's broader view of epistemology. It seems clear that even if natural theology is unnecessary for the rationality of religious faith, it might still have other purposes, so the critique of evidentialism is not fatal to natural theology. In the history of natural theology, it has been motivated not only by the desire to satisfy the demands of rationality, or even only by the desire to find evidential support for religious belief. In addition, natural theology has also been about connecting religious beliefs with the broader world and interpreting all of reality in light of $\operatorname{God}^{16}$, moving towards increased knowledge of God, and even prayer and meditation of the Creator through the creation (McGrath 2016, 163-168). Nevertheless, it does seem true that the need for natural theology is somewhat less pressing once the evidentialist assumption, and evidentialist objections to religious belief are given up. ${ }^{17}$

Plantinga's relationship to natural theology see further Mascord 2007, chapter 6. For a broader overview of the related idea of fideism, see Vainio 2010.

${ }^{16}$ E.g. Macquarrie 1975, 137: “We could say that the function of natural theology was to provide a connection between our ordinary everyday discourse about the world and even our scientific discourse on the one side, and theological discourse on the other."

${ }^{17}$ As Wolterstorff $(1986,39)$ points out, one of Barth's critiques of natural theology was natural theology required faith to desert "its own standpoint" and to take up the contrary "standpoint of unbelief": the believer is staking his or her faith on natural theological arguments. If the grounds of faith are actually much broader, then this helps mitigate Barth's challenge. Through analyzing the natural theology of Thomas Aquinas, Wolterstorff persuasively contends that natural theology does not have to be "evidentialist apologetics" following Enlightenment-Age models. 


\section{The Critique of the Evidences of Natural Theology}

Now on to the critique of the evidences of natural theology (5). As Plantinga (1991, 312; 2000, 32) notes, traditionally natural theological arguments have often been held to a very high standard. In this understanding, theistic arguments were supposed to begin from self-evident premises and move through clear deductive reasoning to the conclusion that God exists. Some of the critiques of Hume and Kant also seem to assume that if there is any doubt about the premises of natural theological arguments, the arguments lose their value. For example, Hume presented the argument that if the designedness of the cosmos can also be explained by positing a finite Creator, then the teleological argument is useless for religious belief. However, with Plantinga, the contemporary discussion has moved away from such high standards. Now theistic arguments can be considered to be good arguments, and to have evidential value, even if they do not establish their conclusion with absolute certainty. Consequently it has become possible for defenders of natural theology to take vastly different positions on how strong the arguments of natural theology are. ${ }^{18}$

On one end of the spectrum, Thomistic natural theologians like Edward Feser (2008) hold that we have extremely strong Aristotelian-Thomistic arguments for the existence of God based on metaphysical premises that are evident to all people based on their ordinary experience, though developments in philosophy have obscured this fact from us. ${ }^{19}$ However, most natural theologians are currently satisfied with merely probable knowledge of God, or simply evidence that makes belief in God justified. Influentially, Richard Swinburne (2004a) presents a Bayesian cumulative case argument for the conclusion that the existence of God is more probable than not based on the evidence. Ninian Smart's (1992) "soft natural theology" is even further down the scale from

\footnotetext{
18 Stephen T. Davis $(1997,189-190)$ presents five possible purposes for arguments of natural theology, from less to more demanding: (1) to show that theists are rational in their belief in the existence of God; (2) to show that it is more rational to believe that God exists than it is to deny that God exists; (3) to show that it is more rational to believe that God exists than to be agnostic on the existence of God; (4) to show that it is as rational to believe in God as it is to believe in many of the things that atheist philosophers often believe in (for example, the existence of "other minds" or the objectivity of moral right and wrong); or (5) to show that it is irrational not to believe that God exists (that is, it is irrational to be either an atheist or an agnostic). (Quoted in McGrew \& DePoe 2013, 301.)

19 See further also White 2016. The idea that natural knowledge of God is so ubiquitous and certain is consistent with the Catholic position expressed in the First and Second Vatican Councils. See e.g. the Vatican II document Dei Verbum, chapter I:6: "As a sacred synod has affirmed, God, the beginning and end of all things, can be known with certainty from created reality by the light of human reason (see Rom. 1:20); but teaches that it is through His revelation that those religious truths which are by their nature accessible to human reason can be known by all men with ease, with solid certitude and with no trace of error, even in this present state of the human race."
} 
Thomistic natural theology. Smart holds that while we do not have convincing evidence either for or against religious belief, we do still have evidence and arguments that are relevant for religious belief. This kind of soft natural theology is still valuable for Smart, since it makes rational discussion of worldviews possible in a pluralistic world.

Sometimes it is difficult to classify natural theologians on this scale of "little evidence" to "strong evidence". This is because, as I will discuss in more depth below, natural theologians also differ on how commonly shared the premises of natural theological arguments are, and how persuasive these arguments can be from the point of view of nonbelievers. For example, Alister McGrath's position is difficult to classify at this point. On the one hand, McGrath argues that the evidence is highly consonant with belief in God, so much so that Christian belief provides the overall "best explanation" of nature. On the other hand, McGrath also argues that nature is ambiguous because of the evil and ugliness it contains, and that the status of Christianity as the best explanation can only be perceived after reason is illuminated by the light of Christ. (McGrath 2016, 73-78)

I will continue the analysis of McGrath's thought below. But I do want to note that the concept of ambiguity is also present to some extent in the other natural theologians. For example, Feser and Swinburne would also acknowledge that there are many people who think that the evidence is highly ambiguous. However, they could argue that what matters is not how people perceive the evidence, but how good the evidence and arguments of natural theology actually are, even if some people are prevented from perceiving the strength of the evidence by factors such as the influence of bad philosophy in Western culture or the bad noetic effects of human $\sin .^{20}$ There may also be theological reason to except some ambiguity to the evidence. C. Stephen Evans (2010) argues that while signs of God are ubiquitous in the created world, some ambiguity to the evidence is also theologically desirable. This is because while we would expect God to leave signs of himself, we would also expect him to leave us some way of resisting belief in him. Taking this kind of position allows natural theologians to accept the ambiguity of the evidence, and yet believe that evidence is valuable for belief in God.

\footnotetext{
${ }^{20}$ Thus White $(2016$, xxv) argues that the idea that all humans have the capacity for natural knowledge of God "need not entail the belief that such a non-Christian realization of natural knowledge of God even occurs at all (although, like Aquinas, I consider this point of view to be mistaken.) Even less is it a claim that this natural dimension of the person in the fallen state must or can be awakened without the work of grace. Grace can be given, after all, even to heal "merely" natural capacities afflicted by ignorance or the disorders of the will and the emotions."
} 
Natural theology is usually understood as an enterprise providing arguments supporting belief in God. However, this is not the only way that natural theology has been understood: even Lord Gifford's definition of natural theology is focused on natural "knowledge of God". The Giffordian definition does stipulate that natural theology is a like science, which would seem to imply the use of arguments and evidence in natural theology. However, suppose that it is possible to have natural knowledge of God without arguments. Might the reliability of this knowledge be defended in a natural theology without presenting any of the traditional arguments for God's existence? Hume's contemporary Thomas Reid (1710-1796) provides the groundwork for such views by arguing that belief in the designedness of the cosmos is based on a non-inferential capacity to detect design. Just as we perceive that other humans have minds, and that human artifacts are purposefully created, so too we also perceive that there is a Creator of nature. According to Reid, design arguments can act to reinforce the reliability of this initial perception, but such arguments are not necessary for natural knowledge of God. ${ }^{21}$

One argument along these lines is defended Mats Wahlberg (2012). To defend the possibility of reliably perceiving design in biological nature, Wahlberg presents a deep analysis of the nature of perceptual beliefs, as well as of compatibility of Darwinian evolutionary biology and this noninferential belief. Wahlberg concludes that it is still reasonable to see biological nature as a natural revelation of the Creator, and as providing a powerful reason for this belief. Wahlberg's approach is not simply a restatement of intuitions about nature, but a systematization of purported natural knowledge of God and the discussion of it in relation to the natural sciences. For Wahlberg, the perception of design in biology also helps make religious belief in a Creator intelligible. So, whatever we think of the merits of this approach, it does satisfy many of the characteristics of natural theologies. ${ }^{22}$

\section{The Critique of Natural Theology's Relationship with Confessional Theology}

Regarding the critique of natural theology's relationship with confessional theology (6), natural theologians have to take a position on two different main questions: (1) How comprehensible is God and how do our concepts apply to him? (2) What is proper relationship between natural and

${ }^{21}$ Essays on the Intellectual Powers of Man (1785), essay V.

${ }^{22}$ For further analysis of Wahlberg's approach and similar arguments by Plantinga and others, see Kojonen $2016 c$. 
revealed theology? Different answers to these questions create large differences between natural theologies.

As the first theological question (1), how comprehensible is God and how do our concepts apply to him? Natural theologians will need to say that our expressions about God succeed in pointing to him at least in some way. Yet a common critique of natural theology is that it commits the "ontotheological" error by equating the being of God and the being of creatures. Some theologians are hesitant to even say that God exists, since (the argument says) this might make God into just another being among beings, a part of the world, thus compromising the infinite qualitative distinction between the Creator and his creation. (E.g. Macquarrie 1977, 118. See further McCordAdams 2014; Marion 2016) Natural theologians can take different positions here. Denys Turner (2004) argues that to avoid the error requires simultaneously affirming both God's unknowability and his knowability. Claiming that God is wholly other and that human concepts cannot be applied to him would make God irrelevant to humans and dismiss the central Christian doctrines of God's revelation and incarnation. However, believing that we can wholly comprehend God would lead to creating a false image of God to fit into our philosophies. For Turner, the key is that in proving the existence of God (or at least providing evidence supporting this belief) natural theology is proving the existence of a mystery that reason cannot fully grasp. Thus natural theology seems in principle compatible also with negative theology, and does not have to overly emphasize the likeness of God and the world. ${ }^{23}$ Turner argues that properly understood, as natural theology leads us to understand that God exists and that God has certain attributes, it also leads us to understand God's transcendence and mysteriousness. Thomistic natural theologians like Turner are careful to emphasize the difference between God and humans, keeping to Thomas' analogical understanding of theological language (See also Feser 2008, White 2016, Stump 2016).

As Alston (2005) points out, contemporary Anglo-American philosophical theologians generally trust in the capacity of the human reason to understand quite a lot of the properties and intents of God, though no-one believes that they fully comprehend God. Many natural theologians adopt a univocal understanding of theological language. It is emphasized that we must be able to

\footnotetext{
${ }^{23}$ A similar point is made by Augustine: "though the voices of the prophets were silent, the world itself, by its wellordered changes and movements, and by the fair appearance of all visible things, bears a testimony of its own, both that it has been created, and also that it could not have been created save by God, whose greatness and beauty are unutterable and invisible." (De civitate dei, XI, 4).
} 
understand what we mean by terms like "person" or "existence" when we apply them to God, and that the use of such terms does not need to mean that God is in all respects like a human person. ${ }^{24}$ Swinburne's (2004a) natural theology, for example, depends on our ability to understand God's moral reasoning. This allows the Swinburnean natural theologian to say that a certain kind of world is more likely on the hypothesis that God exists than on any competing hypothesis. Without assuming that humans can understand God's motivations, this kind of natural theology becomes impossible. ${ }^{25}$ Thus differences in how we understand theological language and the mysteriousness of God can result in large differences in how we construct natural theological arguments.

The second theological question (2) on which natural theologians differ concerns the proper relationship between natural theology and divine revelation. The question is multifaceted, but often arises from the consideration of the noetic effects of human sin. To what extent is natural knowledge of God possible to humans even given the noetic consequences of human sin? Is natural knowledge of God possible only for believers, illuminated by the grace of God, but not for nonbelievers? Historically Christian natural theologians have admitted that natural knowledge of God is fallible and prone to error. For example, Thomas Aquinas argued that "the truth about God such as reason could discover would only be known by a few, and that after a long time, and with the admixture of many errors." (Summa Theologica, 1.1.) Luther's critique of the theology of glory also emphasizes how human sin distorts natural theology, so that whatever correct knowledge of God people attain to is useless for salvation. ${ }^{26}$ Thomas Woolford (2011) argues that the extent to

\footnotetext{
${ }^{24}$ For different perspectives of how we can talk of God's "properties", see also Holmes 2007, Wainwright 2009 and Williams 2005. For whether the critique might apply to Intelligent Design as a form of natural theology, see Kojonen 2016a, chapter 6.

${ }^{25}$ Dawes $(2009,46-48)$ argues that the analogical nature of theological language harms the explanatory power of the arguments of natural theology.

${ }^{26}$ See the article by Ilmari Karimies in this issue. As a related point, the relationship between the natural theologians' "God of the philosophers" and the God of the Bible is also a point of contention. Is the "God of the philosophers" described by natural theology the same God as the biblical God? Do we need to begin our theological discourse from Christ and the Trinitarian understanding, or could it be possible to begin from a general philosophical theism and then accept Trinitarianism as a specification of that theism? Turner (2004,17-20) considers the issue on the basis of Aquinas' writings. Here I want to simply note that the question of reconciling different understandings of God is not a problem that arises simply outside of biblical theology, but also arises from within the Christian tradition and the Bible. For example, the prophets of the Old Testament do not talk of the Trinity, yet the Christian tradition identifies the God of Abraham, Isaac and Jacob as the Trinitarian God. The Christian tradition includes the idea of progressive revelation, where not all truth about God was clear instantly, but was progressively revealed. The question also arises naturally from within the religious life: what guarantees that I now worship the same God as I did as a child, when my understanding of God has changed considerably? It is not just natural theologians who have to worry about reconciling different ideas of God. And if the problem can be solved in these cases inside Christian theology, why not also between natural theology and revealed theology? Of course, in addition to the
} 
which natural knowledge of God was possible already based on natural revelation was one of the dividing lines between Catholics and Protestants in the Reformation period. Whereas Catholics believed that natural knowledge of God was possible already before the infusion of saving grace and before entering the Church, Protestants tended to believe that natural theology was able to attain only to limited knowledge of God, and only when the operation of reason was corrected by saving grace. ${ }^{27}$ Nevertheless, in these historical examples, no necessary opposition between natural theology and revealed theology exists. Indeed, as Pannenberg (1991, 73-118) argues, natural theology was historically quite typically considered to build on divine self-revelation in nature.

Related to this, natural theologians can differ on the proper starting point of theology, and how natural theology is related to systematic theology. Should natural theology stand as the judge of what purported "special revelation" is the most likely to be the revelation of the true God, and perhaps even change religious beliefs based on its arguments? Should natural theology seek to begin from premises shared by both the believer and the nonbeliever, then perhaps ultimately leading to the recognition of a religious tradition as supplementing this natural theology? Or should natural theology be done beginning from openly confessional theological premises, attempting to connect some religious tradition to the broader world and culture? In the next section, I will briefly compare Richard Swinburne's and Alister McGrath's approaches related to this.

\section{Comparing Two Approaches to Natural Theology}

One possibility is to begin defending the rationality of Christian belief in God by first defending the rationality of a more generic form of theism, as Swinburne (2004a) does. Building on the overall probability of the existence of God, Swinburne (2003) then constructs what he calls a "ramified" natural theology, a natural theology supplanted with additional ideas and evidence to go beyond bare theism. According to Swinburne, the historical evidence makes it highly probable that Jesus rose from the dead and was God incarnate. Based on belief in the resurrection of Jesus, it then becomes probable that the teaching of the Church which Jesus founded is reliable. This comes

doctrine of God, the possibility of reconciliation will depend on the broader content of the natural and revealed theologies, as well as how we understand the nature of religious faith.

${ }^{27}$ However, see Sudduth (2009) for a more positive view of the natural theology of the Reformers. 
close to the approach of theologian Wolfhart Pannenberg (1977), who similarly argues that the historical credibility of Jesus' resurrection is essential for the credibility of Christian theology. ${ }^{28}$ Swinburne's natural theology ends in a fairly traditional Christian understanding of God. ${ }^{29}$ However, it is in principle possible for this kind of approach, beginning from general natural theological considerations, to end up with a less traditional view. For example, in a defense of process theology, theologian David Ray Griffin (2013) argues that the results of the natural sciences and philosophical considerations based on the problem of evil heavily mitigate against the traditional theistic understanding of God's omnipotence. According to Griffin, the convergence of philosophical and scientific arguments points instead towards the process theologian's understanding of God. In a sense this kind of natural theology is the kind of result that Barth wanted to avoid, since here the doctrine of God is so greatly influenced by reason. The natural theologian attracted to process thought may retort by arguing that Barth was wrong and that it is better to build our doctrine of God using all of the evidence, including the deliverances of reason.

In contrast to Swinburne, McGrath's (2016) natural theology begins from within the Christian tradition. Following Barr (1994) and others, McGrath argues the Bible and the Christian tradition themselves contain good motivations for natural theology. The doctrine of humanity as the image of God capable of rationality, the idea that God has created an orderly, intelligible world and the idea of natural revelation are all Christian ideas. Beginning from robustly theological premises, natural theology is then about interpreting nature through the Christian lens and finding connections or "resonance" with the world. Christian doctrine can have an explanatory dimension even if this theology is also about much more. Ultimately, McGrath argues, using the terminology provided by Lipton (2004), that Christianity provides the "best explanation" of the world. However, he also argues that we lack any neutral standpoint from which to evaluate the explanatory merits of Christianity. ${ }^{30}$ In order to recognize the appeal of the Christian way of thought, one must already step mentally inside the Christian framework. McGrath's purpose is to present natural theology as a fundamentally Christian enterprise, rather than an alien invader to

\footnotetext{
${ }^{28}$ Again, note that neither Swinburne nor Pannenberg would argue that all believers need to first do this kind of evidential work before believing in the Christian God. On the relatioship of Pannenberg's and Swinburne's natural theology, see further Holder 2012, chapter 4. On ramified natural theology, see Menuge \& Taliferro ed. 2013.

${ }^{29}$ However, note that there is debate over how traditional Swinburne's theistic personalism is when compared with classical theism. See e.g. Philipse ed 2008.

${ }^{30}$ Here McGrath references the work of Alasdair McIntyre (1988) and others.
} 
theology, as Barth conceived it. In this way, McGrath's form of natural theology is not the same type of natural theology that Barth criticized.

But is it natural theology at all? It could be argued that McGrath's approach is closer to the approach Ian G. Barbour $(1997,100)$ termed "a theology of nature", rather than a natural theology. ${ }^{31}$ In Barbour's terminology, natural theologies seek to provide support for religious beliefs beginning from premises that have independent justification from any religious tradition. The direction is from universal experience towards the knowledge of God. In contrast, theologies of nature begin from within some religious tradition and then seek to form a theological interpretation of nature. Here the direction goes from pre-existing belief in God to connecting this belief with outside data, such as the natural sciences. So, natural theology is about the understanding seeking faith, whereas theologies of nature are about "faith seeking understanding" - fides quarens intellectum. ${ }^{32}$

However, I think two main considerations favor thinking of McGrath's theological engagement with nature as a natural theology. First, if we accept the view of natural theology as a collection of characteristics, we might argue that McGrath's natural theology shares enough of these characteristics to still qualify as a natural theology. He clearly holds to theological realism, believes that the creation reflects its Creator, accepts the value of evidence for religious faith, and uses many of the same evidences used by other natural theologians.

Second, it is difficult to see how McGrath could consistently deny that there exists evidential support for Christian belief from commonly available evidence. Since McGrath believes that Christian theology provides the best explanation for all of reality, using the best standards of logic and reasoning, then it seems reasonable to think that nonbelievers might also be able to recognize that at least some evidence supports Christianity. To use a metaphor: when a good bridge over a river has been build, it is usually possible to travel on the bridge in both ways. McGrath himself does also believe that the explanatory power of Christian theology has value in apologetics, and has the habit of inviting his listeners to consider how much sense things make from a Christian standpoint. While his natural theology does not begin as an attempt to prove or justify Christian

\footnotetext{
31 This is argued by Padgett (2004) \& Runehov (2010).

32 McGrath $(2016,176)$ argues that his approach has much commonality with the theology of nature developed by Robert J. Russell $(1998,196)$. For a more extensive development of Russell's approach, see Russell 2008.
} 
belief, but as a faith seeking understanding, McGrath acknowledges that the positive outcome of this seeking is "itself evidencing faith." $(2016,176)$

An evidentialist may also agree with McGrath that Christian theologians do not have to begin by demonstrating the truth of the Christian revelation in a way that convinces all people before starting to do theology. (Visala 2016) Swinburne also does not argue that notions of rationality are wholly shared, or that the Christian must begin his or her own worldview-building from a neutral standpoint. His argument is simply that in defending the rationality of belief in God, we should appeal to publicly available evidence, and further that there is enough common ground that even a secular philosophy might support Christian truths "in some respect". (Swinburne 1993, 197) Furthermore, as noted above, a natural theologian might value evidence in the consideration of religious truths without holding that religious belief must always be based on grounds that can be shared across traditions. The merits of a "ramified natural theology" may even be discussed simply for the purposes of argument, without assuming that the believer may not have broader grounds for her religious belief. ${ }^{33}$

Critics might argue that the credibility of Swinburne's natural theology is also dependent on prior Christian belief in a sense. Consider his argument for the resurrection of Jesus. Swinburne argues that there is at least a modest probability that a good God would want to become incarnate, and to die a vicarious atoning death to save humanity from its sins. Swinburne presents moral grounds for thinking that such action from God is at least possible, and argues that this possibility is corroborated by the historical evidence. ${ }^{34}$ Swinburne provides arguments for the plausibility of his premises which attempt to make them credible also for nonbelievers. However, it might be argued that these intuitions about morality have been formed in a Christian culture, and that Swinburne's natural

\footnotetext{
${ }_{33}$ Mikael Stenmark $(1995,325-327)$ provides an interesting metaphor for why a religious believer might consider it useful to engage in a theoretical discussion about evidence for the existence of God, even if belief in God is not primarily a hypothesis for the believer. Consider my belief that my wife loves me. This belief is grounded in my entire life experience with my wife, and my belief in them is not a hypothesis. Nevertheless, suppose that someone else does not believe that my wife loves me, or has doubts about her virtuous character. I could in principle discuss some evidences of this love, even though it will be difficult to convey the full grounds of my own beliefs. Similarly, Stenmark argues that a religious believer may discuss God's existence as a hypothesis and attempt to present evidence for it, though the grounds for that religious belief may be broader and not entirely communicable.

${ }^{34}$ In contrast to Swinburne, Timothy McGrew (2012) argues that the historical evidence for Jesus' resurrection is so strong that it is able to overcome even an extremely low prior probability to the resurrection. This argument requires much more of the historical evidence, but is less susceptible to the criticism that the credibility of the priors is too dependent on pre-existent Christian belief.
} 
theology thus does not completely evade the tradition-dependent nature of rationality. Arguably the Ancient Pre-Christian world had very different ideas about morality. Despite any common ground between Christian doctrine and pagan philosophy, the idea of a crucified God (which Swinburne believes dates back to the very earliest Christianity) was revolutionary, and appeared preposterous to many of early Christianity's critics on philosophical grounds. (Hart 2009) It might thus be argued that the plausibility of Swinburne's presuppositions is also in a sense dependent on our historical situation. ${ }^{35} \mathrm{My}$ point here is not to take a strong stance on this issue, but simply to highlight that the tradition-dependence of natural theology is another issue which natural theologians need to have a stance on. McGrath embraces the tradition-dependence of rationality, though as a critical realist he also believes in the possibility of the tradition of natural theology to get ever closer to truth. It may be fair to say, as Rodney Holder (2012, chapter 6) argues that typically natural theologians emphasize the idea that there is also something about rationality that transcends particular traditions more than McGrath does. ${ }^{36}$ McGrath (2016) himself emphasizes that he is simply presenting a nuanced approach to natural theology that attempts to do justice to the actual complex situation we find ourselves in. ${ }^{37}$

\footnotetext{
${ }^{35}$ For some critical reviews of Swinburne's argument, see Wiebe 2009 and Otte 2003.

${ }^{36}$ The fact that the ideas used in natural theological arguments can often be traced back to a religious tradition need not be a negative thing for the credibility of the arguments. For example, Robin Collins (2012) emphasizes that explanations of the fine-tuning of the laws of nature must not be ad hoc. According to Collins, the fact that belief in a Creator God who values the existence of life predated the discovery of cosmic fine-tuning helps show that theism is not such an ad hoc explanation.

${ }^{37}$ Natural theologians can differ on how much common ground there is between humans based on our common experience. Even if human experience is always conditioned by contingent factors, there may still be much common ground between different traditions. Despite the vast differences between Christian theology and Ancient Greek philosophy in Antiquity, there was also some common ground, and the Christian Fathers were able to utilize and transform some philosophical concepts in developing theology. (For one overview, see Pelikan 1997.) However, Jenson (2001, 6-11) argues that Greek philosophy was simply Greek theology, and that there is also today no reason to think that philosophers have any more rational authority to talk about God than theologians do. Thus for Jenson natural theology is not really natural, but always the theology of some particular group in a particular contingent historical situation. Jenson's purpose is to safeguard the epistemic primacy of biblical revelation in doing theology. As he writes: "Barth did not declare independence from 'the philosophers' because philosophy is something so different from theology that it must be kept at arm's lenght. His reason was exactly the opposite: he refused to depend on the official philosophers because what they offered to do for him he thought he should do for himself, in conversation with them when that seemed likely to help." (Jenson 2001, 21). But if one accepts the idea that some experiences and ideas of rationality might be common to all of humanity, then Jenson's critique of natural theology is no longer convincing.
} 


\section{Conclusion: On the Evolution of Natural Theology}

My purpose in this paper has been to analyze the overall broad contours of the responses that are natural theologians have made to the traditional critiques raised against their enterprise. I have argued that natural theology has evolved in response to the critique. I have outlined how contemporary natural theologians differ in their responses to the eight main issues: (1) the importance of evidential support for religious faith, (2) the force of the evidences of natural theology (3) which evidences of natural theology are the most convincing, and what form natural theological arguments should take, (4) the nature of theological language, (5) the understanding of God that natural theology supports, (6) the relationship between natural and revealed theology, (7) the proper starting point of natural theology, and (8) how much common basis for dialogue exists between believers and nonbelievers.

Differences in opinion on each of these eight points can be very large, and natural theologians often argue against each other. Nevertheless, from the amount and quality of the discussion that exists, it seems clear that natural theologians have at least attempted to adapt to (and develop responses to) the critiques presented by Hume, Kant, Darwin, Barth and others. Thus critics of natural theology should not think that quickly referring to these critiques is sufficient to refute all contemporary natural theology.

Natural theologians should of course seek to reconcile their differences on these issues and find the best approach on each question. However, while we wait for the emergence of such a consensus, I believe the variety of forms taken by natural theology also helps explain how it has been able to survive despite all of the critique it has faced. Barth $(1946,76)$ famously likened natural theology to a snake: "you hit it and kill it as soon as you see it." My point in bringing up this quote is not to comment on Barth's critique of natural theology further than I have already done. Rather, I want to consider the metaphor of natural theology as a biological species further. In the wild, a species able to adapt to environmental changes is less likely to go extinct. The malleability of natural theology similarly makes this species able to spread to many different theological and cultural environments and hard to kill. Some form of natural theology may thus be able to survive even in an environment that is somewhat hostile to other forms of natural theology.

For example, suppose that in a given environment, it is generally accepted that natural theological arguments fail to prove God's existence. A natural theologian with a great deal of confidence in 
the available evidence may try to challenge this presupposition. However, the natural theologian can also adapt to the environment and agree that no proof of God is forthcoming. This in itself still leaves room for natural theology to raise the intellectual credibility of belief in God in some way (the precise nature of which will be determined by the epistemological view accepted in that environment), thus maintaining belief in God as a "live option", to use William James' term (1896, 329). Of course, some objections to natural theology are too fundamental to be adapted to in this way. For example, the critic of natural theology may not concede the relevance of evidence for religious faith at.

The malleability of natural theology is not the only reason for its survival, of course. Other reasons have also been proposed in the literature. For example, it may be that natural theology is "natural" to our kinds of intellects in the sense that (as many cognitive scientists of religion argue) our minds find it easy to interpret the world as one created by a supernatural being. (De Cruz and De Smedt 2015). Furthermore, whatever the reason, the evidences appealed to in natural theology continue to be convincing for many people. Those who experience the evidences as forceful are unlikely to want to eliminate natural theology, since they have the experience that natural theology is giving them something good. Furthermore, there is at least the perception that many of the goals of natural theology, such as apologetics to those outside the faith and intellectual confirmation to those inside the faith, cannot be fulfilled without a natural theology. As long as it is not shown that these goals are not valuable or that they can be fulfilled in other ways, the possibility of a natural theology will continue to have appeal..$^{38}$

\section{Bibliography}

Alston, William. 1967. "Religion." The Encyclopedia of Philosophy. Ed. P. Edwards. New York, NY: Macmillan. 140-145.

1991. Perceiving God: The Epistemology of Religious Experience. Ithaca, NY: Cornell

University Press.

\footnotetext{
${ }^{38}$ Indeed, another way to criticize natural theology would be to argue that there are other goals which are in contradiction with the goals of natural theology, and are also more important to pursue than the goals of natural theology. For example, Barth clearly understands the need to engage the surrounding culture, but for him the need to preserve the purity of Christian doctrine trumps any need for a natural theology. Vainio (2010, chapter 3) presents an excellent analysis of how different focusing on different goals has lead to great differences in theological method within contemporary theology.
} 
1995. "The Place of Experience in the Grounds of Religious Belief." Our Knowledge of God: Essays on Natural and Philosophical Theology. Ed. Kelly James Clark. Dordrect: Kluwer Academic Publishers. 87-112.

2005. "Two Cheers for Mystery." God and the Ethics of Belief: New Essays in the Philosophy of Religion. Eds Andrew Dole Andrew and Andrew Chignell. Cambridge, UK: Cambridge University Press.

Barbour, Ian. 1997. Religion and Science: Historical and Contemporary Issues. San Francisco, CA: HarperOne.

Barr, James. 1994. Biblical Faith and Natural Theology. The Gifford Lectures for 1991: Delivered in the University of Edinburgh. New York, NY: Oxford University Press.

Barth, Karl. 1946 [1934]. “No!” Natural Theology: Comprising “Natural and Grace” by Professor Dr Emil Brunner and the Reply “No!” by Dr. Karl Barth. Translated by Peter Fraenkel. Introduction by John Baillie. London: Greffrey Bles. 65-128. 2005 [1938]. The Knowledge of God and the Service of God According to the Teaching of the Reformation. The Gifford Lectures Delivered in 1937 and 1938. Translated by J. L. M. Haire \& Ian Henderson. Eugene, OR: Wipf \& Stock.

Brooke, John Hedley. 2002. "Natural Theology." Science and Religion: a Historical Introduction. Ed. Gary Ferngren. Baltimore, MA: The John Hopkins University Press.

Brooke, John Hedley \& Cantor, Geoffrey. 2000. Reconstructing Nature : the Engagement of Science and Religion. Edinburgh : T\&T Clark, 2000.

Chignell, Andrew. 2009. "'As Kant Has Shown': Analytic Theology and the Critical Philosophy." Analytic Theology: New Essays in the Philosophy of Theology. Ed. Oliver Crisp \& Michael Rea. Oxford: Oxford University Press. 116-135.

2016. “The Ethics of Belief.” The Stanford Encyclopedia of Philosophy (Spring 2016

Edition). Ed. Edward N. Zalta. Available at:

$<$ http://plato.stanford.edu/archives/spr2016/entries/ethics-belief/>.

Clark, Kelly James. 2014. Religion and the Sciences of Origins: Historical and Contemporary Discussions. New York, NY: Palgrave Macmillan.

Clifford, W. K. 1877 [1999]. "The Ethics of Belief". The Ethics of Belief and Other Essays. Ed. T. Madigan. Amherst, MA: Prometheus, 70-96.

Collins, Robin. 2012. "The Teleological Argument." The Blackwell Companion to Natural Theology. Eds William Lane Craig and J.P. Moreland. Malden, MA: Wiley-Blackwell. 202-281.

Craig, William and Moreland, J.P. Eds. 2012. The Blackwell Companion to Natural Theology. Oxford: Blackwell Publishing.

Davis, Stephen T. 1997. God, Reason and Theistic Proofs. Grand Rapids, MI: Eerdmans. 
Dawes, Gregory A. 2009. Theism and Explanation. New York, NY: Routledge.

De Cruz, Helen \& De Smedt, Johan. 2015. A Natural History of Natural Theology: The Cognitive Science of Theology and Philosophy of Religion. Cambridge, MA: The MIT Press, 2015.

De Ridder, Jeroen; Peels, Rik \& van Woudenberg, René. Forthcoming. Scientism: Prospects and Problems. Oxford: Oxford University Press.

Evans, C. Stephen. 2010. Natural Signs and Knowledge of God: A New Look at Theistic Arguments. Oxford: Oxford University Press.

Feser, Edward. 2008. The Last Superstition: A Refutation of the New Atheism. South Bend, IN: St Augustine's Press.

Gifford, Adam. 1885. The Will of Lord Adam Gifford. Available at $<$ http://www.giffordlectures.org/lord-gifford/will>. Accessed on June 8, 2016.

Griffin, David Ray. 2013. "Process Thought and Natural Theology." The Oxford Handbook of Natural Theology. Ed. Russell Re Manning. Oxford: Oxford University Press. 276-294.

Hart, David Bentley. 2009. Atheist Delusions: The Christian Revolution and Its Fashionable Enemies. New Haven, CT: Yale University Press.

Holder, Rodney. 2012. The Heavens Declare: Natural Theology and the Legacy of Karl Barth. West Conshohocken, PA: Templeton Press.

Holmes, Stephen R. 2007. "The Attributes of God." The Oxford Handbook of Systematic Theology. Eds John Webster, Kathryn Tanner and Iain Torrance. Oxford: Oxford University Press. 54-71.

Hume, David. 2008a. An Enquiry Concerning Human Understanding. Ed. Peter Millican. Oxford: Oxford University Press.

University Press. 2008b. Dialogues Concerning Natural Religion. Ed. J. C. A. Gaskin. Oxford: Oxford James, William. 1896. “The Will to Believe." The New World. Vol. 5. 327-347. Houghton: Mifflin \& Co.

Jenson, Robert. 2001. Systematic Theology, Volume 1: The Triune God. Oxford: Oxford University Press.

Kant, Immanuel. 1957 [1781]. Critique of Pure Reason. Translation by N.K. Smith. London: Macmillan.

Keller, John A. 2014. "Theological Anti-Realism." The Journal of Analytic Theology. Vol. 2. 10.12978/jat.2014-1.091413100417a 
Kojonen, Erkki Vesa Rope. 2016a. The Intelligent Design Debate and the Temptation of Scientism. London: Routledge.

2016b. "The God of the Gaps, Natural Theology and Intelligent Design." The Journal of Analytic Theology. Vol. 4. 10.12978/jat.2016-4.041708101413a

2016c. "Salvaging the Biological Design Argument in Light of Darwinism?" Theology \& Science. Vol. 14. No. 3. 361-381. 2016.

2016d. "Methodological Naturalism and the Truth Seeking Objection." The International Journal for Philosophy of Religion. Published as Online first, DOI 10.1007/s11153-016-95750.

Lipton, Peter. 2004. Inference to the Best Explanation. London: Routledge.

Macquarrie, John. 1975. Thinking about God. London: SCM Press. 1977. Principles of Christian Theology. Revised Edition. London: SCM Press.

Marion, Jean-Luc. 2016. Givenness and Revelation. Oxford: Oxford University Press.

Mascord, Keith. 2007. Alvin Plantinga and Christian Apologetics. Eugene, OR: Wipf \& Stock.

McCarthy, Gerald D. 1986. The Ethics of Belief Debate. Atlanta, GA: Scholar's Press.

McCord-Adams, Marilyn. 2014. "What's Wrong with the Ontotheological Error?" Journal of Analytic Theology. Vol. 2. 10.12978/jat.2014-1.120013000318a.

McCormack, Bruce. 1995. Karl Barth's Critically Realistic Dialectical Theology. Oxford: Clarendon Press.

McGrath, Alister. 2009. A Fine-Tuned Universe: The Quest for God in Science and Theology. Louisville, KN: Westminster John Knox Press. 2016. Re-Imagining Nature: The Promise of a Christian Natural Theology. Hoboken: Wiley.

McGrew, Timothy. 2012. "The Argument from Miracles: A Cumulative Case for the Resurrection of Jesus of Nazareth." The Blackwell Companion to Natural Theology. Eds J.P. Moreland and William Lane Craign. Oxford: Blackwell. 593-662.

McGrew, Timothy \& DePoe, John. 2013. "Natural Theology and the Uses of Argument." Philosophia Christi. Vol. 15. No. 2. 299-310.

McIntyre, Alasdair. 1988. Whose Justice? Which Rationality? Notre Dame, MD: University of Notre Dame Press.

Menuge, Angus \& Taliaferro, Charles. Ed. 2013. Special Issue of Philosophia Christi on Ramified Natural Theology. Winter 2013.

Moore, Andrew. 2013. "Theological Critiques of Natural Theology." The Oxford Handbook of Natural Theology. Ed. Russell Re Manning. Oxford: Oxford University Press. 227-244. 
Nielsen, Kai. 2004. Naturalism and Religion. New York, NY: Prometheus Books.

Otte, Richard. 2003. "Review of The Resurrection of God Incarnate, Richard Swinburne." Notre Dame Philosophical Reviews. 2003.09.04.

Padgett, Alan G. 2004. “Theologia Naturalis: Philosophy of Religion or Doctrine of Creation?” Faith and Philosophy. Vol. 21. No. 4. 493-502.

Pannenberg, Wolfhart. 1977. Jesus: God and Man. $2^{\text {nd }}$ Edition. Philadelphia, PA: Westminster. 1991. Systematic Theology. Vol. 1. Edinburgh: T \& T Clark.

Pelikan, Jaroslav. 1997. What Has Athens to Do with Jerusalem? Timaeus and Genesis in Counterpoint. University of Michigan Press. Ann Arbor, MI: University of Michigan Press.

Penelhum, Terence. 2005. "Hume's Criticisms of Natural Theology." In Defense of Natural Theology: A Post-Humean Assessment. Ed. James F. Sennett \& Douglas Groothuis. Downer's Grove, IL: InterVarsity Press.

Phillips, D. Z. Ed. 2008. Whose God? Which Tradition? The Nature of Belief in God. London: Routledge.

Phillips, D. Z. 1988. Faith after Foundationalism. London: Routledge.

Plantinga, Alvin. 1982. "The Reformed Objection to Natural Theology." The Christian Scholars Review. Vol. 11. 187-198.

1990 [1967]. God and Other Minds: A Study of the Rational Justification of Belief in God. Ithaca, NY: Cornell University Press.

1991. "The Prospects for Natural Theology." Philosophical Perspectives. Vol. 5. 287-315 2000 Warranted Christian Belief. New York, NY: Oxford University Press.

Rauser, Randall. 2009. "Theology as Bull Session." Analytic Theology: New Essays in the Philosophy of Theology. Ed. Oliver Crisp \& Michael Rea. Oxford: Oxford University Press. 70-84.

Rosenberg, Alex. 2011. The Atheist's Guide to Reality: Enjoying Life without Illusions. New York, NY: W. W. Norton \& Co.

Rossi, Philip. 2014. "Kant's Philosophy of Religion." Stanford Encyclopedia of Philosophy. Fall 2014 Edition. Ed. Edward N. Zalta. Available at <http://plato.stanford.edu/archives/fall2014/entries/kantreligion/>.

Runehov, Anne L.C. 2010. "Natural Theology or Theology of Nature and the Natural?" The Human Project in Science and Religion. Copenhagen University Discussions in Science and Religion. Eds. Anne L.C. Runehov, Niels Henrik Gregersen and Jacob Wolf. Copenhagen: Publications from the Faculty of Theology. No. 20.

Russell, Paul. 2014. "Hume on Religion." The Stanford Encyclopedia of Philosophy (Winter 2014 Edition). Ed. Edward N. Zalta. Available at $<$ http://plato.stanford.edu/archives/win2014/entries/hume-religion/>. 
Russell, Robert J. 1998. "Special Providence and Genetic Mutation: A New Defense of Theistic Evolution." Ed. Robert J. Russell, William R. Stoeger, S. J and Francisco J. Ayala. Vatican City State; Berkeley, California: Vatican Observatory Publications; Center for Theology and the Natural Sciences. 194-95.

2008. Cosmology from Alpha to Omega: The Creative Mutual Interaction of Theology and Science. Minneapolis, MN: Fortress Press.

Sennett, James F. \& Groothuis, Douglas. Eds. 2005. In Defence of Natural Theology: A Post-Humean Assessment. Downers Grove, IL: InterVarsity Press.

Smart, Ninian. 1992. "Soft Natural Theology." Prospects for Natural Theology. Ed. Eugene Thomas Long. Washington, D.C. : The Catholic University of America Press. 198-206.

Stenmark, Mikael. 1995. Rationality in Science, Religion and Everyday Life: A Critical Evaluation of Four Models of Rationality. Notre Dame, IN: University of Notre Dame Press. 2001. Scientism: Science, Ethics and Religion. Burlington: Ashgate.

Stump, Eleonore. 2016. The God of the Bible and the God of the Philosophers. The Aquinas Lectures Vol. 80. Milwaukee, WI: Marquette University.

Sudduth, Michael. 2009. The Reformed Objection to Natural Theology. Burlington: Ashgate.

Swinburne, Richard. 2003. The Resurrection of God Incarnate. Oxford: Oxford University Press. 2004a The Existence of God. Oxford: Oxford University Press.

2004b "Natural Theology, its 'Dwindling Probabilities' and 'Lack of Rapport'”. Faith and Philosophy. Vol. 21. No. 4. 533-546.

Tahko, Tuomas E. 2015. An Introduction to Metametaphysics. Cambridge: Cambridge University Press.

Taliaferro, Charles. 2012. "The Project of Natural Theology." The Blackwell Companion to Natural Theology. Eds. William Lane Craig and J.P. Moreland. Oxford: Blackwell. 1-23.

2013. "Philosophical Critique of Natural Theology." The Oxford Handbook of Natural Theology. Ed. Russell Re Manning. Oxford: Oxford University Press. 385-394.

Turner, Denys. 2004. Faith, Reason and the Existence of God. Cambridge: Cambridge University Press.

Vainio, Olli-Pekka. 2010. Beyond Fideism: Negotiable Religious Identities. Burlington, VT: Ashgate.

von Loewenich, Walter. 1976. Luther's Theology of the Cross. Belfast: Christian Journals.

Wahlberg, Mats. 2012. Reshaping Natural Theology: Seeing Nature as Creation. London: Palgrave Macmillan.

Wainwright, William J. 2009. "Theology and Mystery." The Oxford Handbook of Philosophical Theology. Eds Thomas P. Flint and Michael C. Rea. Oxford: Oxford University Press. 78-102. 
White, Thomas. 2016. Wisdom in the Face of Modernity: A Study in Thomistic Natural Theology. $2^{\text {nd }}$ Edition. Ave Maria, FL: Sapientia Press.

White, Thomas. Ed. 2010. The Analogy of Being: Invention of the Antichrist or Wisdom of God? Grand Rapids, MI: Wm. B. Eerdmans Publishing Company.

Williams, Thomas. 2005. "The Doctrine of Univocity is True and Salutary." Modern Theology. Vol. 21. No. 4. 575-585.

Visala, Aku. 2016. "What Does Theology Have to Do With Evidence? Exploring Analytic Theology and Epistemology." Journal of Analytic Theology. Vol. 4. 10.12978/jat.2016-4.001020210800a

Wiebe, Phillip. 2009. “Review of Richard Swinburne, Was Jesus God?" Notre Dame Philosophical Reviews 2009.03.32.

Woolford, Thomas A. 2011. Natural Theology and Natural Philosophy in the Late Renaissance. University of Cambridge Doctoral Dissertation.

Wolterstorff, Nicholas. 1986. "The Migration of the Theistic Arguments: From Natural Theology to Evidentialist Apologetics." Rationality, Religious Belief, and Moral Commitment. Ed. William Wainwright \& Robert Audi. Cornell University Press. 38-81. 